\title{
Uptake and Translocation of a Systemic Fungicide, S-7131 in Cucumber Plant
}

\author{
Yoshio Hisada, Kiyoto Maeda, Yasuo Kawase and Junshi Miyamoto \\ Research Department, Pesticides Division, Sumitomo Chemical Co., Ltd., \\ Takarazuka, Hyogo 665, Japan
}

(Received December 19, 1975)

\begin{abstract}
Systemic movements of carbonyl-14 C-S-7131 $\left[N-\left(3^{\prime}, 5^{\prime}\right.\right.$-dichlorophenyl)-1, 2-dimethylcyclopropane-1,2-dicarboximide] were examined in cucumber plants. When ${ }^{14} C-\mathrm{S}-7131$ was applied to the first true leaf, it readily penetrated into the leaf and moved beyond the treated leaf both upward and downward. And also, the evidence was obtained that the fungicide was readily taken up through the roots and translocated to aerial parts of the plant. S-7131 which had once reached a certain leaf tended to accumulate in the leaf margins. The translocation of S-7131 into distal parts was also shown in the experiment using bioassay for local systemic activity. In TLC analysis of methanol-extractable radioactive substances, only a few breakdown products were detected 12 days after foliar application of ${ }^{14} \mathrm{C}-\mathrm{S}-7131$. At this time, intact $\mathrm{S}-7131$ accounted for about $80 \%$ of the radioactivity recovered from each segment of the plants. This result shows that S-7131 per se is active as a systemic fungicide within cucumber plant. In both foliar and root applications, the amount of S-7131 translocated into the non-treated parts of cucumber plant was sufficient to prevent from gray mould attack.
\end{abstract}

\section{INTRODUCTION}

A fungicide, S-7131 $\left[N-\left(3^{\prime}, 5^{\prime}-\right.\right.$ dichlorophenyl)-1,2-dimethylcyclopropane-1,2-dicarboximide] is highly effective for controlling bean Sclerotinia rot and cucumber gray mould caused by Sclerotinia sclerotiorum and Botrytis cinerea, respectively. ${ }^{4}$ Effectiveness of S-7131 in practical control of diseases has been presumed to be due to high residual activity on host plants, protective as well as curative action, and considerable systemic activity in plants. The discovery of oxathiins, ${ }^{9)}$ pyrimidines, ${ }^{3)}$ and benzimidazoles ${ }^{2)}$ led to the recognition that their systemic movements in plants are practically significant for the control of plant diseases. Efficiency of systemic fungicides is dependent on coverage of susceptible foliage, flower, and fruit parts without spray deposits and attack against pathogens deeply seated in the tissues. It is important to know behavior of a systemic fungicide on or in plants, not only to elucidate its mode of action but also to increase the efficiency of its use. The present study using ${ }^{14} \mathrm{C}$-labeled S-7131 provides additional evidence that the fungicide moves systemically in cucumber plants, and elucidates the distribution pattern of S-7131 within cucumber plants in detail.

\section{MATERIALS AND METHODS}

\section{Plants}

Two-week old cucumber plants (Cucumis sativus L. cv. Kurumeochiai $\mathrm{H}$-type) grown in soil contained in plastic pots in a greenhouse were used throughout this study.

\section{Fungicide and Its Application to Plants}

Carbonyl $-{ }^{14} C-\mathrm{S}-7131$ was synthesized in this laboratory ${ }^{8}$ and had a specific activity of $4.67 \mathrm{mCi} / \mathrm{mmole}$. Nonlabeled and ${ }^{14} \mathrm{C}$-labeled S-7131 were formulated by adding nine parts of a mixture of emulsifying agent (Hymal PS-10AS, Matsumoto Yusi Seiyaku) and isophorone $(1 / 9, \mathrm{w} / \mathrm{v})$ to one part of the compound. Water suspension of the fungicide was prepared at a concentration of $500 \mathrm{ppm}$ 


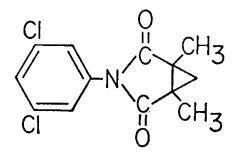

Fig. 1 The chemical structure of S-7131.

as an active ingredient, unless otherwise indicated.

Foliar application of ${ }^{14} \mathrm{C}$-S-7131 was conducted by spreading $200 \mu \mathrm{l}$ of the fungicide suspension per leaf on the upper surface of the first true leaf. In root application, roots of the plant were washed with tap water and then placed into an Ehlenmyer flask with $100 \mathrm{ml}$ of Kasugai's nutrient solution containing $5 \mathrm{ppm}{ }^{14} \mathrm{C}-\mathrm{S}-7131$. The treated plants were kept in a greenhouse until sampling.

\section{Sampling and Analytical Procedure}

In foliar application of ${ }^{14} \mathrm{C}-\mathrm{S}-7131$, the plants harvested at various time intervals were separated to the treated leaf, shoot and root moieties. Upper surface of the treated leaf was washed three times with $15 \mathrm{ml}$ of acetone. In root application, the plants were divided into the shoot and root moieties. Each segment of the plants was weighed, frozen and stored until analysis. Three plants were sampled at every harvest.

Plant materials were homogenized with $3 \mathrm{ml}$ of methanol per $\mathrm{g}$ of fresh weight in a mortar and pestle. After filtration through a filter paper, the residue was reextracted with methanol. The combined filtrate was assayed for radioactivity. The residue was dried and combusted for radio-assay by a Sample-Oxidizer (Packard, Tri-Carb 306). Aliquotes of the methanolic extracts were subjected to thin layer chromatography (TLC) using silica gel $\mathrm{F}_{254}$ precoated plate with a gel thickness of $0.25 \mathrm{~mm}$ (Merck). The TLC plates were developed in a solvent system, benzen/ethyl acetate $(1 / 1, \mathrm{v} / \mathrm{v})$. Localization of radioactive bands on the chromatogram was determined by autoradiography. The radioactive zone was scraped from the plate into counting vials and assayed for radioactivity.

\section{Radio-Assay}

Radioactivity was quantitatively measured on a liquid scintillation spectrometer (Packard, Tri-Carb 3375). All samples were counted as homogeneous solution in a scintillation solution composed of $5 \mathrm{~g}$ of 2,5-diphenyloxazole and $100 \mathrm{~g}$ of naphthalene in $1,000 \mathrm{ml}$ of dioxane.

\section{Autoradiography}

Autoradiographic technique was used to determine translocation of ${ }^{14} \mathrm{C}$ in the plants and radioactive regions on TLC plates. After harvest the plant was placed between sheets of filter paper and dried by heating with an iron at $85^{\circ} \mathrm{C}$. The dried plants and TLC chromatograms were exposed to nonscreen type industrial Fuji X-ray film (No. 150) for a week in the dark.

\section{Bioassay}

Local systemic activity of the fungicide in the first true leaf was estimated by bioassay. This test involved half leaf treatments where the fungicide suspension was sprayed to the proximal, the distal, or the lateral half. Five days after treatment, inoculation was carried out by placing a $5 \mathrm{~mm}$ agar disc with growing mycelia of Botrytis cinerea on the non-sprayed half which had been detached from the treated plant. The inoculated leaves were placed in a dark moist chamber maintained at $20^{\circ} \mathrm{C}$. Three days later, assessment of disease development was made by measuring the diameter of the lesion. Assays were made with five plant replicates. The amount of S-7131 in the leaf tissue of cucumber plant was determined by bioautography as reported previously.4)

\section{RESULTS}

Carbon-14-labeled S-7131 which had been applied to the upper surface of the first true leaf readily penetrated into the treated leaf and moved beyond its leaf both upward and downward. Figure 2 represents the patterns of distribution of ${ }^{14} \mathrm{C}$ to the treated leaves and other plant parts. Uptake of ${ }^{14} C$ by the plants rapidly increased untill 3 days after treatment. Most of ${ }^{14} \mathrm{C}$ in the treated leaves was taken up during 1 day. The amount of 


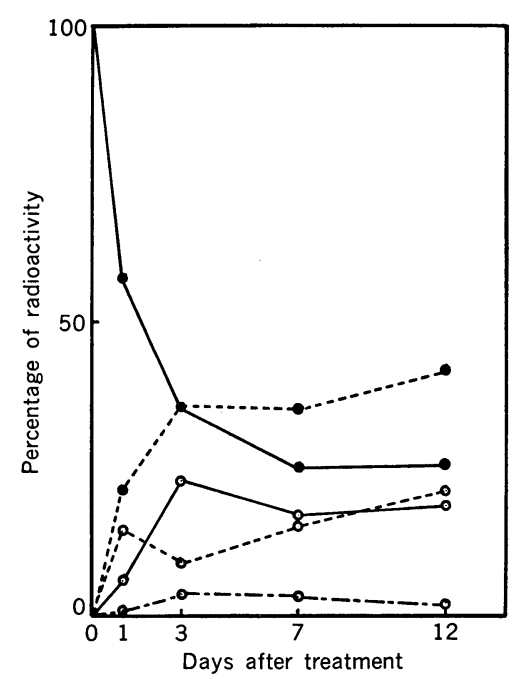

Fig. 2 Percentage distribution of total ${ }^{14} \mathrm{C}$ in segments of cucumber plants after foliar application of ${ }^{14} \mathrm{C}$-S-7131. -.- total in plants, - - surface, ○-.-○ treated leaves, $\bigcirc-\bigcirc$ shoots, O---O roots.

total ${ }^{14} C$ translocated from the treated leaves to the shoots and roots became maximum after 3 days. The concentrations of ${ }^{14} \mathrm{C}$-S 7131 in the shoots and roots were 11.2 and $1.7 \mu \mathrm{g} / \mathrm{g}$ of fresh weight, respectively 3 days

Table 1 The concentration of S-7131 in cucumber plants on application of ${ }^{14} \mathrm{C}$ S-7131 to the first true leaves.

\begin{tabular}{lccc}
\hline $\begin{array}{c}\text { Plant } \\
\text { parts }\end{array}$ & $\begin{array}{c}\text { Days } \\
\text { after } \\
\text { treatment }\end{array}$ & $\begin{array}{c}\text { Fresh } \\
\text { weight of } \\
\text { tissues } \\
\text { (g) }\end{array}$ & $\begin{array}{c}\mu \mathrm{g} \text { of S-7131/g } \\
\text { fresh weight } \\
\text { of tissues }\end{array}$ \\
\hline Treated & 1 & 5.8 & 4.9 \\
leaves & 7 & 6.1 & 4.5 \\
& 12 & 6.8 & 6.4 \\
& 1 & 7.4 & 7.2 \\
\hline & 3 & 7.3 & 1.9 \\
Shoots* & 7 & 12.5 & 11.2 \\
& 12 & 25.8 & 1.2 \\
& 1 & 6.6 & 0.4 \\
Roots & 3 & 6.8 & 1.7 \\
& 7 & 8.1 & 1.3 \\
& 12 & 12.2 & 0.4 \\
\hline
\end{tabular}

* Airial parts without the treated leaf. after the treatment, and thereafter rapidly decreased with increase of fresh weight of the plants due to growth (Table 1). In the treated leaves, the concentration of ${ }^{14} \mathrm{C}-\mathrm{S}-7131$ was 4.0 to $6.5 \mu \mathrm{g} / \mathrm{g}$ of fresh weight depending on period of exposure. The autoradiograms showed translocation of ${ }^{14} C$ within the plant. High radioactivity in a petiole of the treated first true leaf, a petiole and veins of the second true leaf, a developing young shoot, a stem below the treated leaf, and a basal part of root was observed on the autoradiogram 3 days after the treatment (Fig. 3-a). After 7 days ${ }^{14} C$ in veins of the second true leaf uniformly distributed into the mesophyll tissues (Fig. $3-b)$. At this time the second true leaf was inoculated with $B$. cinerea. A little accumulation of radioactivity was noted at the affected lesion 2 days after inoculation (Fig. $3-c)$. The autoradiograms of the plant on day 12 showed migration of ${ }^{14} C$ to leaf margins (Fig. 3-d). The experiment for local systemic activity in the first true leaf using bioassay also showed that the fungicide tended to preferentially move to distal direction (Table 2).

Uptake of ${ }^{14} \mathrm{C}-\mathrm{S}-7131$ from the culture solution by the roots and upward translocation rapidly occurred; the autoradiogram showed that as early as 4 hours after the treatment, an appreciable amount of ${ }^{14} \mathrm{C}$ was taken up by the roots and translocated to a stem, petioles and veins of both the first and second true leaves (Fig. 3-e). However, at this time ${ }^{14} C$ was not translocated yet to the mesophyll tissues. With lapse of time, ${ }^{14} C$ was gradually translocated to the mesophyll

Table 2 Local systemic activity of S-7131 on bioassay test*.

\begin{tabular}{cc}
\hline $\begin{array}{l}\text { Inoculated parts } \\
\text { of cucumber leaf }\end{array}$ & $\begin{array}{c}\text { Severity of infection } \\
\text { (Percentage of nonsprayed } \\
\text { control) }\end{array}$ \\
\hline Distal half & 21 \\
Proximal half & 45 \\
Lateral half & 34 \\
\hline
\end{tabular}

* A half of cucumber leaf was sprayed with S7131 and another half was inoculated by $B$. cinerea 5 days later. 


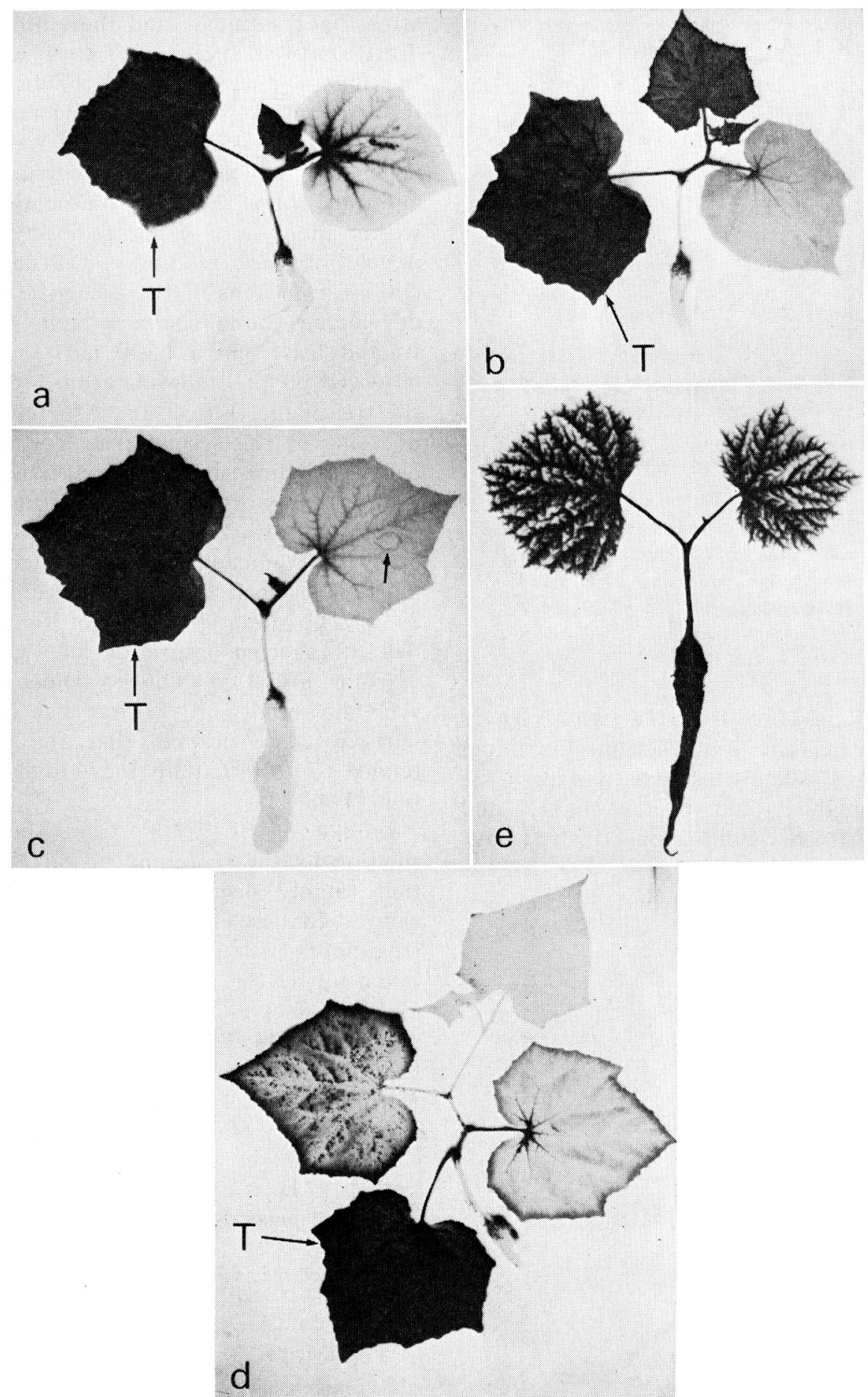

Fig. 3 Autoradiographs of cucumber plants; $T$, treated leaf. a. 3 days after foliar application of ${ }^{14} \mathrm{C}-\mathrm{S}-7131$. b. 7 days after foliar application of ${ }^{14} \mathrm{C}-\mathrm{S}-7131$. c. The second true leaf of plant at (b) was inoculated with $B$. cinerea $(2$ days after inoculation); a little accumulation of radioactivity is noted at affected lesion (arrow). d. 12 days after foliar application of ${ }^{14} \mathrm{C}-\mathrm{S}-7131$. e. 4 hours after root application of ${ }^{14} \mathrm{C}-\mathrm{S}-7131$ in the culture nutrient solution. 
Table 3 Thin layer chromatography of radioactive compounds extracted from cucumber plants treated with ${ }^{14} \mathrm{C}$-S- $7131^{*}$.

\begin{tabular}{lcrrr}
\hline \multirow{2}{*}{$\begin{array}{l}\text { Radio- } \\
\text { active } \\
\text { bands }\end{array}$} & Rf & \multicolumn{3}{c}{ Percentage composition } \\
\cline { 3 - 5 } & & $\begin{array}{c}\text { Treated } \\
\text { leaves }\end{array}$ & Roots & Shoots \\
\hline 1 (S-7131) & 0.54 & 81.1 & 82.0 & 80.2 \\
2 & 0.48 & 5.9 & 3.3 & 7.6 \\
3 & 0.26 & 1.2 & 1.5 & 1.1 \\
4 & 0.05 & 0.9 & 1.5 & 1.9 \\
5 & 0.00 & 10.9 & 11.7 & 9.2 \\
Total & & 100.0 & 100.0 & 100.0 \\
Recovery & & 89.0 & 90.0 & 88.5 \\
\hline
\end{tabular}

* 12 days after application of ${ }^{14} \mathrm{C}-\mathrm{S}-7131$ to the first true leaves.

tissues. Percentage of recoveries of ${ }^{14} \mathrm{C}$ from the plants exposed to ${ }^{14} \mathrm{C}-\mathrm{S}-7131$ for 7 days were $56.6 \%$ in the shoots and $17.4 \%$ in the roots; concentrations of ${ }^{14} \mathrm{C}-\mathrm{S}-7131$ in the shoots and roots were 21.1 and $32.6 \mu \mathrm{g} / \mathrm{g}$ fresh weight, respectively.

More than $97 \%$ of radioactivity in each segment of the plants treated with ${ }^{14} \mathrm{C}-\mathrm{S}-7131$ was extractable with methanol. The methanolic extracts contained one major and four minor radioactive bands when analyzed by TLC (Table 3 ). The major radioactive band agreed with the authentic S-7131 on cochromatography. Twelve days after application of ${ }^{14} \mathrm{C}-\mathrm{S}-7131$ to the first true leaf, about $80 \%$ of the radioactivity in methanolic extracts obtained from all parts of cucumber plants was accounted for as intact S-7131.

\section{DISCUSSION}

In the previous paper, we reported bioassay data indicating upward translocation of S-7131 into the cotyledons of cucumber seedlings through the roots. ${ }^{4)}$ In this study we confirmed systemic movements of S-7131 in cucumber plants by use of the ${ }^{14} \mathrm{C}$-labeled compound. When applied to the first true leaf of cucumber plants, S-7131 was readily absorbed by the leaf and translocated both upward and downward directions: in root application ${ }^{14} \mathrm{C}-\mathrm{S}-7131$ was readily taken up by the roots immerged in the culture solution and immediately translocated to the plant parts above the roots.

S-7131 tended to translocate into young growing parts rather than into already matured leaves at the time of the treatment. This characteristic movement of S-7131 was also observed when the fungicide was applied to cucumber plants as a soil drench. ${ }^{5)}$ Furthermore, translocation into the leaves that had not yet appeared at the time of treatment was also observed. S-7131 which had once reached a certain leaf has a tendency to accumulate in the leaf margins with a concomitant depletion in the central area of the leaf. Twelve days after foliar application of the fungicide, this tendency was obviously recognized (Fig. 3-d). The preferential movement of S-7131 to distal direction was also observed in the experiment using bioassay technique for local systemic activity. This property of S-7131 to move within cucumber plant is similar to that of systemic fungicide benomyl which moves in the apoplast. ${ }^{1,6,7)}$

Our previous study using a bioautographic technique indicates that S-7131 per se is active as a systemic fungicide within cucumber plants. Results obtained with TLC analysis of methanol-extractable radioactive substances furnished further evidence that most of ${ }^{14} \mathrm{C}$ found in plants was accounted for as the intact molecule. Intact S-7131 amounts to about $80 \%$ of the radioactivity recovered from each segment of plants 12 days after foliar application of ${ }^{14} \mathrm{C}-\mathrm{S}-7131$. The radioactivity in the residue which was not extractable with methanol was less than $3 \%$ of the total radioactivity contained in each segment of plants. This fact indicates that binding of S-7131 with the materials of cucumber plant seldom occurs.

Based on quantitative analysis of S-7131 in the leaves of cucumber plants by bioautography, 10 to $20 \mu \mathrm{g}$ of the fungicide per $\mathrm{g}$ fresh weight of the leaves controlled disease development of gray mould by 80 to $90 \%$. These results indicate that the maximum amount of S-7131 found in the shoot after either foliar or root application is sufficient to control gray mould attack. In foliar application, however, time-course change in concentrations (Table 1) and distribution 
pattern without uniformity (Fig. 3) of the fungicide in shoot indicates that every part of shoot may be not sufficiently protected. Thus, S-7131 translocated into the nontreated parts of cucumber plant is able to contribute to prevention against attack of pathogenic fungi. Additionally, a little accumulation of radioactivity at the lesion affected by gray mould suggests that S-7131 suppresses more effectively further development of the disease.

\section{ACKNOWLEDGEMENT}

The authors are indepted to Dr. T. Kato for helpful discussions on several points in the paper.

\section{要約}

${ }^{14} C$ で標識した S-7131 [N-(3', 5'-ジクロルフェニル) -1,2-ジメチルシクロプロパソ-1, 2-ジカルボキシイミ ド]の植物体中への浸透移行性についてキュウリを使用 して検討した. ${ }^{14} \mathrm{C}-\mathrm{S}-7131$ を第一本葉に叙布した場合, 薬片は処理葉内に容易に吸収され，上部および下部の無 処理組織に移行するのが認められた。本薬剤は根からも 容易に吸収され，速やかに地上部に移行した。無処理葉 に移行した S-7131 は，しだいにその葉の周縁部に集積 する傾向を示した. 葉面処理した植物をメタノールで抽
出して得た放射活性物質を薄層クロマトグラフィーで分 析した，処理12日後においてもわずかな量の分解物しか 認められなかった．植物の地上部，地下部組織および処 理葉のいずれにおいても，それぞれに含まれる全放射活 性の約 80\% が未变化の S-7131 に相当した. このこと は S-7131 それ自体が植物体内を浸透移行し，活性を発 揮していることを示唆している. 葉面処理および根部処 理のいずれにおいても，植物の無処理部分に移行した S-7131 の量は，灰色かび病を防除するのに十分であっ た.

\section{REFERENCE}

1) W.L. Biehn \& A.F. Dimond: Plant Dis. Reptr. 54, 12 (1970)

2) C.J. Delp \& H.L. Klopping: ibid. 52, 95 (1968)

3) R.S. Elios, M.C. Shephard, B. K. Snell \& J. Stubbs: Nature 219, 1160 (1968)

4) Y. Hisada, K. Maeda, N. Tottori \& Y. Kawase: J. Pesticide Sci. 1, 145 (1976)

5) Y. Hisada \& K. Maeda: Unpublished (1975)

6) C.A. Peterson \& L.V. Edgington: Phytopathology 60, 475 (1970)

7) C.A. Peterson \& L.V. Edgington: ibid. 61, 91 (1971)

8) H. Tsunematsu \& A. Yoshitake: Unpublished (1975)

9) B. Von Schmeling \& M. Kelka: Science 152, 659 (1966) 